\title{
Drivers of the Second Wave and clinical characteristics of COVID-19 cases in Uganda: A Retrospective Study of Confirmed SARS-CoV-2 cases, March-June, 2021
}

\section{Abel Wilson Walekhwa}

Makerere University Faculty of Medicine: Makerere University College of Health Sciences

\section{Brenda Nakazibwe}

Makerere University Medical School: Makerere University College of Health Sciences

\section{Mary Nantongo}

Makerere University Medical School: Makerere University College of Health Sciences

\section{Solomon Tsebeni Wafula}

Makerere University Faculty of Medicine: Makerere University College of Health Sciences

Douglas Bulafu

Makerere University Medical School: Makerere University College of Health Sciences

Brenda Ayugi

Makerere University Medical School: Makerere University College of Health Sciences

\section{Caroline Nankabirwa}

Makerere University, College of Veterinary Medicine, Animal Resources and Biosecurity

\section{Godfrey Nsereko}

Makerere University Medical School: Makerere University College of Health Sciences

\section{Martha Dorcas Nalweyiso}

Makerere University

\section{Tonny Tindyebwa}

Makerere University Medical School: Makerere University College of Health Sciences

\section{Roy William Mayega}

Makerere University Medical School: Makerere University College of Health Sciences

Abel Bulamu Ekiri

University of Surrey School of Veterinary Medicine

\section{Danstan Bagenda}

University of Nebraska Medical Center College of Medicine

\section{Monica Musenero}

Ministry of Science, Technology and Innovation, Office of the President, Uganda

Lawrence Mugisha ( $\nabla$ mugishalaw@gmail.com ) 
Makerere University, College of Veterinary Medicine, Animal Resources and Biosecurity https://orcid.org/0000-0003-4932-3356

\section{Research Article}

Keywords: COVID-19, SARS-CoV-2, Drivers, Uganda, Second wave, Asymptomatic

Posted Date: January 25th, 2022

DOl: https://doi.org/10.21203/rs.3.rs-1253445/v1

License: (9) This work is licensed under a Creative Commons Attribution 4.0 International License. Read Full License 


\section{Abstract}

\section{Background}

The COVID-19 continued to pose several public health, social, economic challenges and the drivers for the occurrence of different COVID-19 waves remains undocumented in Uganda. We conducted a crosssectional population-based survey among recovered COVID-19 cases to establish the drivers of SAR-CoV2 infections.

We performed a retrospective study and interviewed 1120 recovered COVID-19 cases from 10 selected districts in Uganda. We further conducted 38 Key Informant Interviews of members of the COVID-19 District Taskforce and 19 in-depth interviews among COVID-19 survivors from March to June, 2021.

\section{Results}

Out of the 1120 recovered COVID-19 cases interviewed, $62 \%$ were aged 39 years and below and $51.5 \%$ females with $90.9 \%$ under home based care management. Cases were more prevalent in business (25.9\%), students (17.2\%), farmers (17.1\%) and health workers (12.4\%) and 79.9\% developed COVID-19 symptoms mainly cough, flu, and fever. Being asymptomatic was found to be associated with not seeking healthcare (APR $2, \mathrm{P}<0.001)$. The mortality rate was $3.7 \%$ mostly among the elderly $(6.3 \%)$ and $31.3 \%$ aged 40 years and above had comorbidities of high blood pressure, diabetes and asthma. High blood pressure and diabetes were significantly associated with low survival rate $(P<0.001)$ among the COVID-19 cases.

\section{Conclusions}

Our study identified several drivers under the broad categories of demographic, patient, health facilities and services, social and economic factors that attributed to emergence and sustenance of COVID-19 second wave from March to June, 2021. Specifically, being female, young, asymptomatic, under Home Based Care Management, social gatherings, school going, not vaccinated were among the major drivers of the second wave. We strongly recommend that the Ministry of Health together with National Taskforce for COVID-19 Response to reconsider some aspects of Home-Based Care Management to only established institutions and organizations with potential and facilities to monitor cases in addition to training and monitoring all those involved in supporting the Home Based Care Management.

\section{Background}

Coronavirus disease (COVID-19) has remained a Public Health Emergency of International Concern (PHEIC) almost one and half years after the pandemic was declared a PHEIC in January, 2020 by the World Health Organization (1). To date, nations are still under increased pressure to overcome the spiraling global spread of the deadly novel (COVID-19) which is responsible for more than 266 million infected individuals and over 5.2 million deaths worldwide as of 7th December $2021(2,3)$.The wide and 
unprecedented spread of COVID-19 caused by Severe Acute Respiratory Syndrome Coronavirus 2 (SARSCoV-2) has been attributed to its ability to spread via respiratory droplets, aerosol and secretions facilitated by high level of globalization and international travel (4).

On 21st March 2021, the Ugandan Ministry of Health reported the first case of confirmed COVID 19 in Uganda from a returning passenger through Entebbe International Airport. Uganda continued to register few cases of COVID-19 composed mainly of cross-border truck drivers from neighboring countries until June, 2020 when community transmissions increased marking the first wave of COVID-19 cases $(5,6)$ To curtail the spread of the disease, the government of Uganda instituted public health interventions including border closure, complete lockdown, quarantine, and testing of returnees, contact tracing, and abolishing of public gatherings (7-9).

Following the end of the first COVID-19 wave that subsided in January-February, 2021, most of the instituted control measures were eased especially lockdown measures such as public transport operations while others such as worship places and school openings were relaxed allowing the public to resume normal routines that support their social and economic activities (10). However, few SARS-CoV-2 infections were still being reported in the communities, and later, due to unknown factors triggered an exponential rise of COVID-19 cases in different parts of the country, marking the start of the second wave. The majority of the cases were reported in the capital city, Kampala, regional cities, and border districts with over 900 cases daily and reaching a positivity rate of 17\% by June 2021 (11). The period between March to June 2021 is believed to have marked a clear emergence of the second wave of COVID 19 in Uganda with the highest recorded number of cumulative cases up to 90,000 cases and with over 2,000 deaths as of 20th July 2021 (5).

The number of COVID-19 cases in the second wave was strikingly high, more fatal and widespread in several districts and there was no/limited data to explain the factors associated the observed widespread and impact of COVID 19 among the population. To address this gap, we conducted a retrospective study on recovered confirmed COVID-19 positive PCR-RT/RDT cases from March to June, 2021 from 10 districts that had registered the highest number of COVID-19 cases in the second wave (5).

\section{Results}

Response: A total of 1120 of PCR-Rt and RDT COVID-19 confirmed cases from 10 districts in Uganda completed the survey with $97 \%$ response rate.

\section{Characteristics of COVID 19 cases}

a. Social demographics: Of the COVID-19 cases interviewed, more than half 51.5\% (577/1120) were females. We found increased numbers of cases across all age groups and more occurrences among the young and middle age groups (30-39 years) at 26.8\% (300/1120). Overall, we found increased cases up to $62 \%$ among age group 39 years and below (figure 2). When we adjusted for age, the majority of the cases were among 40 years and above. 
We further found that most of the respondent COVID-19 cases were business men and women $25.9 \%$ (290/1120), followed by students $17.2 \%$ (193/1120), farmers/peasants $17.1 \%(192 / 1120)$, and health workers $12.4 \%(139 / 1120)$. The socio-demographic characteristics of the interviewed cases are summarized in frequencies and percentages (Table 1).

b. Symptoms: Most cases $(79.9 \%, 895 / 1120)$ acknowledged having developed COVID-19 symptoms at a certain point during the course of illness while a small proportion $(17.8 \%, 199 / 1120)$ were asymptomatic (figure 3).

\section{c. Admission Status}

Only $9.1 \%$, of the COVID-19 positive cases were admitted to health facilities (Table 1). According to age group, most cases $31.3 \%$ (130) with underlying conditions were aged 40 years and above. However, an increased number of young people (13-39 years) cases ranging from $13 \%$ (12) to $21 \%$ (63) reported having underlying conditions (Table 2). Among those cases aged 40 years and above, $31.3 \%$ (130) had underlying conditions and many of them were admitted either required oxygen, ventilation or admission to ICU as summarized in Table 3. The most commonly encountered underlying conditions were high blood pressure, diabetes and asthma. High blood pressure and diabetes were significantly associated $(P<0.001)$ with low levels of survival.

Table 2: Number of cases, underlying conditions and need for admission by age group

\begin{tabular}{llllclll}
\hline $\begin{array}{l}\text { Age } \\
\text { group }\end{array}$ & $\begin{array}{c}\text { Cases conditions } \\
\text { Cnderlying }\end{array}$ & $\begin{array}{l}\text { Admitted } \\
\text { facility }\end{array}$ & $\begin{array}{c}\text { to } \\
\text { health Admitted } \\
\text { ICU }\end{array}$ & $\begin{array}{c}\text { to Needed } \\
\text { Oxygen }\end{array}$ & $\begin{array}{l}\text { Needed } \\
\text { ventilation }\end{array}$ & Dead \\
\hline$\leq 5$ & 16 & $1(6.2)$ & 0 & 0 & 0 & 0 & 0 \\
$6-12$ & 46 & $1(2.2)$ & $1(2.2)$ & 0 & 0 & $1(16.7)$ & 0 \\
\hline $13-19$ & 93 & $12(13)$ & $2(2.1)$ & 0 & 0 & $2(10.5)$ & $1(1.1)$ \\
\hline $20-29$ & 250 & $29(11.6)$ & $11(4.4)$ & $1(1.6)$ & $3(4.8)$ & $4(6.4)$ & $3(1.2)$ \\
\hline $30-39$ & 300 & $63(21)$ & $28(9.3)$ & $7(7.1)$ & $11(11)$ & $4(4.1)$ & $11(3.7)$ \\
\hline $40 \geq$ & 415 & $130(31.3)$ & $60(14.5)$ & $19(14)$ & $35(25.7)$ & $15(11.3)$ & $26(6.3)$ \\
\hline
\end{tabular}

Table 3. Vaccination status of COVID 19 patients. 


\begin{tabular}{lll} 
Vaccination status of the cases before testing $(\mathbf{n}=\mathbf{1 0 9 0})$ & Frequency & Percentage (\%) \\
\hline Not vaccinated at all & 878 & 78.4 \\
One dose of AstraZeneca & 166 & 14.8 \\
\hline Two doses of AstraZeneca & 46 & 4.1 \\
\hline Reasons for not being vaccinated against COVID-19 & & \\
\hline Concerns about safety of the vaccine & 231 & 39.4 \\
\hline Vaccines are not accessible & 226 & 38.5 \\
\hline Personal reluctancy (still waiting to see others) & 97 & 16.5 \\
\hline Lacked time or transport & 33 & 5.6 \\
\hline Intention to receive COVID-19 vaccine soon (n= 924) & & \\
\hline No & 382 & 41.3 \\
\hline Yes & 542 & 58.7 \\
\hline
\end{tabular}

\section{d) Vaccination Status}

Majority of the cases investigated $78.4 \%$ (878) had not received any COVID-19 vaccine with only $14.8 \%$ (166) who had received one dose of AstraZeneca Vaccine and only 4.1\% (46) with two doses received among the vaccinated group (figure 3). Furthermore, slightly above average 58.7\% (542/924) reportedly were willing to take COVID-19 vaccine when available. Elderly survivors aged $40-49$ years ( $P R=1.43,95 \%$ $\mathrm{Cl} 1.10-1.84)$ and $\geq 50$ years $(P R=1.52,95 \% \mathrm{Cl} 1.18-1.96)$ were more willing to receive COVID-19 vaccines compared to those below 20 years of age (Table 6).

Table 6: Predictors of health-seeking behavior and intention to take the COVID-19 vaccines. 


\begin{tabular}{|c|c|c|c|c|}
\hline Variables & $\begin{array}{l}\text { Sought care for symptoms } \\
\text { Adjusted PR (95\% CI) }\end{array}$ & $\mathrm{P}$ value & $\begin{array}{l}\text { Intention to receive COVID-19 vaccine } \\
\text { Adjusted PR (95\% CI) }\end{array}$ & $\mathrm{P}$ value \\
\hline \multicolumn{5}{|l|}{ Region } \\
\hline North & 1 & & 1 & \\
\hline East & $0.98(0.94-1.03)$ & 0.499 & $1.08(0.91-1.28)$ & 0.386 \\
\hline Central & $0.94(0.94-0.99)$ & 0.017 & $1.08(0.91-1.27)$ & 0.376 \\
\hline West & $0.99(0.93-1.05)$ & 0.717 & $0.99(0.78-1.26)$ & 0.935 \\
\hline \multicolumn{5}{|l|}{ Gender } \\
\hline Female & 1 & & 1 & \\
\hline Male & $0.97(0.93-1.00)$ & 0.069 & $1.02(0.92-1.14)$ & 0.690 \\
\hline \multicolumn{5}{|l|}{ Age group } \\
\hline$\leq 19$ & 1 & & 1 & \\
\hline $20-29$ & $0.98(0.91-1.05)$ & 0.564 & $1.17(0.95-1.43)$ & 0.145 \\
\hline $30-39$ & $1.01(0.93-1.10)$ & 0.676 & $1.22(0.95-1.57)$ & 0.115 \\
\hline $40-49$ & $1.02(0.93-1.10)$ & 0.730 & $1.43(1.10-1.84)$ & 0.006 \\
\hline $50 \geq$ & $1.01(0.93-1.10)$ & 0.826 & $1.52(1.18-1.96)$ & 0.001 \\
\hline \multicolumn{5}{|l|}{ Household size } \\
\hline$\leq 5$ & 1 & & 1 & \\
\hline $6-8$ & $1.00(0.95-1.04)$ & 0.856 & $0.96(0.85-1.09)$ & 0.553 \\
\hline $9 \geq$ & $1.03(0.93-1.07)$ & 0.926 & $1.07(0.91-1.25)$ & 0.405 \\
\hline \multicolumn{5}{|l|}{ Occupation } \\
\hline Business & 1 & & 1 & \\
\hline Student & $1.02(0.95-1.11)$ & 0.543 & $1.33(1.07-1.67)$ & 0.011 \\
\hline Farmer/peasant & $0.99(0.93-1.05)$ & 0.659 & $0.86(0.71-1.05)$ & 0.147 \\
\hline Health worker & $1.06(1.01-1.12)$ & 0.035 & $1.37(1.16-1.63)$ & $<0.001$ \\
\hline Other Occupations & $1.00(0.94-1.05)$ & 0.885 & $1.11(0.95-1.29)$ & 0.190 \\
\hline \multicolumn{5}{|c|}{ Had an underlying health problem } \\
\hline No & 1 & & 1 & \\
\hline Yes & $1.04(1.01-1.09)$ & 0.022 & $1.08(0.94-1.23)$ & 0.289 \\
\hline
\end{tabular}

\section{e). Survival status}

Only $3.7 \%,(41 / 1079)$ of the cases died of COVID 19 during the second wave. The elderly 50 years and above were 8 times more likely to die after adjusting the prevalence ratio 8.0 (1.04-61.52). We further noted cases of death in the age group starting from 20-49 years of age with slightly more numbers among 30-39 years represented by the prevalence ratio of 3.8 (Cl: 0.47-31.1). Among those who were vaccinated with at least one dose of the vaccine were 6 times more likely to survive compared to those not vaccinated as per adjusted prevalence ratio 6.1 (3.24-11.57) (Table 4). 
Table 4. Factors associated with survival among the COVID-19 cases

\begin{tabular}{|c|c|c|c|c|c|c|c|}
\hline \multirow[t]{2}{*}{ Factor } & \multirow[t]{2}{*}{ Variables } & \multicolumn{2}{|c|}{ Died $(n=41)$} & \multicolumn{2}{|c|}{ Survived ( $\mathrm{n}=1079$ ) } & \multirow[t]{2}{*}{ Crude PR/95\% CI } & \multirow[t]{2}{*}{ Adjusted PR/95\% CI } \\
\hline & & No. & $\%$ & No & $\%$ & & \\
\hline \multirow[t]{2}{*}{ Gender } & M & 20 & $3.7^{+}$ & 523 & 96.3 & 1.0 & \\
\hline & $\mathrm{F}$ & 21 & $3.6^{+}$ & 556 & 96.4 & $1.0(0.54-1.80)$ & \\
\hline \multirow[t]{5}{*}{ Age group } & $\leq 19$ & 01 & 0.6 & 154 & 99.4 & 1.0 & \\
\hline & $20-29$ & 03 & 1.2 & 247 & 98.8 & $1.9(0.20-17.74)$ & 1.9 (0.19-17.97) \\
\hline & $30-39$ & 11 & 3.7 & 289 & 96.3 & 5.7 (0.74-43.66) & $3.8(0.47-31.1)$ \\
\hline & $40-49$ & 05 & 2.6 & 188 & 97.4 & $4.0(0.47-34.05)$ & $3.5(0.41-29.34)$ \\
\hline & $50 \geq$ & 21 & 9.5 & 201 & 90.5 & $14.7(1.99-107.96)$ & $8.0(1.04-61.52)^{*}$ \\
\hline \multirow[t]{2}{*}{ Sought care } & No & 04 & 5.1 & 74 & 94.9 & 1.0 & \\
\hline & Yes & 33 & 3.6 & 882 & 96.4 & $0.7(0.256-1.93)$ & \\
\hline \multirow[t]{2}{*}{ Was symptomatic } & No & 04 & 2.0 & 195 & 98.0 & 1.0 & \\
\hline & Yes & 35 & 3.9 & 860 & 96.1 & $2.0(0.699-5.41)$ & $1.1(0.37-2.95)$ \\
\hline \multirow[t]{2}{*}{ Admission status } & No & 22 & 2.2 & 996 & 97.8 & 1.0 & \\
\hline & Yes & 19 & 18.6 & 83 & 81.4 & $8.6(4.82-15.37)$ & $6.1(3.24-11.57) *$ \\
\hline \multirow[t]{2}{*}{ Vaccination Status } & No & 33 & 3.8 & 845 & 96.2 & 1.0 & \\
\hline & Yes & 04 & 1.9 & 208 & 98.1 & $0.5(0.18-1.4)$ & $0.5(0.19-1.39)$ \\
\hline
\end{tabular}

\section{Correlates/ driversof the COVID-19 pandemic}

\section{a. Being Asymptomatic.}

A small proportion $(17.8 \%, 199 / 1120)$ were asymptomatic (Table 1). At bivariate analysis, results showed that; not seeking care (CPR 1.99, P-value 0.003), not being admitted (CPR 2.15, P 0.013) and other household members not having symptoms ( $C P R$ 1.52, $P$ 0.001) were positively associated with being asymptomatic among the COVID-19 cases (Table 5). While a household size of greater than 9 members (CPR 0.63, P 0.025), and having contact with others two weeks before testing (CPR 0.38, P 0.000) were likely to be symptomatic among the COVID-19 cases. The details of the bivariate analysis (Table 4).

\section{b. Health seeking behaviors}

Most respondents $81.7 \%$ (915) sought care after noticing symptoms of COVID-19. A total of $79.4 \%$ (823) tested after feeling COVID-19 like signs and symptoms followed by those who had been in contact with a confirmed case 19\% (197). Participants from the central region prevalence ratio 0.94 (0.94-0.99 95\% Cl) were less likely to seek care for COVID-19 symptoms while health workers PR $1.06(1.01-1.12)$ and 
persons with underlying health problems PR $1.04(1.01$ - 1.09) had more proactive health-seeking behaviours. Although a high number $88.3 \%$ (946) sought remedies recommended by a health worker, a good substantial number $70.4 \%$ (754) also drunk herbal concoctions. It was noted that all COVID-19 patients sought more than one remedy (Table 6).

\section{a. Home Based Care (HBC)}

Most of the confirmed cases $90.9 \%$ (1,017/1120) were treated from their home under HBC. COVID-19 cases under HBC management were reported to having continued to move freely within communities as reported per statement quotes of Key Informants and in-depth interviews (table 8). Some respondents considered hospital care as too expensive while others had mild symptoms, even some were asymptomatic.

\section{b. Social gatherings}

Most respondents had visited various places or attended social gatherings: markets (20.3\%), clinic/hospital (17.6\%), and places of worship (10.7\%), high risk towns or districts (10.7\%), and mass gatherings such as funerals (13.7\%) before developing/testing for COVID-19. 21.5\% (241/1120) had contacts with COVID-19 like symptoms persons while 18.2\% (204/1120) did not have any contact and $59.9 \%(671 / 1120)$ did not know of any contacts with any one with COVID-19 like symptoms 2 weeks before onset of symptoms (Table 1). The contacts with COVID-19 like symptoms persons were mainly with family members and friends (54.9\%), co-workers $(25.2 \%)$, and classmates for students $(9.0 \%)$ as per stamen quotes (table 8). Burial places were also reported to have contributed to further spread as bereaved members of the families and communities insisted on cultural practices of burials that increased congestion without adhering to recommended SOPs (Table 8).

\section{c. Myths, misconceptions, and misinformation:}

Respondents of the KIls reported that some members of the communities studied believed there was no COVID-19 and therefore ignored the instructions for observation of SOPs while others depended on the fake social media news to inform their response to instituted SOPs (Table 8).

\section{d. Politics:}

Respondents reported that the political season that started in August, 2020 till February, 2021 as the country was undergoing the first wave of COVID-19 could have facilitated wide community transmissions triggering the second wave of COVID 19 (Table 8).

\section{e. Schools:}

Respondents mentioned that the number of COVID-19 cases among the on-going school pupils and students had increased and were being under reported. Upon closure of the schools as part of the lockdown instituted early in June 2021, some pupils and students from boarding schools who were 
asymptomatic for COVID-19 returned home and unknowingly infected members of their families (Table 8).

\section{f. Weak Health Systems:}

Respondents reported that inadequate resources in most health facilities across the country led to most of the confirmed COVID-19 cases being sent home for HBC management. This led to having so many positive COVID-19 cases in the communities that might have led to rapid spread of infections in the community highlighted by high positivity rates recorded in June, 2021 (table 8). Furthermore, respondents castigated that lack of resources for nationwide sensitization, asymptomatic infected health workers returning to their families, congestion in lower health facilities, limited testing centers, congestion at various trade points exchanging money and goods were among the drivers of COVID-19 in the second wave (Table 8).

\section{g. Stigma to COVID-19}

Respondents reported several non-disclosures of the COVID-19 status especially among asymptomatic cases to avoid being discriminated and harassed in the community leading to indirect exposure of the virus to other unsuspecting members of the community (Table 8 ).

\section{Discussion}

In this study, we assessed the drivers of the second wave of SARS-CoV-2 infections between March and June 2021 from 10 districts in Uganda. In the second wave of COVID-19, we found a slightly higher proportion of female cases compared to males. Our results represent a shift from the first wave where males were mostly affected $(12,13)$ as has been reported elsewhere $(14,15)$. In our study, the change in gender infection status with more females being infected and together with their social roles in families and communities facilitates close interactions with households and communities with more likelihood of increasing transmissions. We further noted increased cases among all age groups with more cases recorded in the young people aged 19 to 39 years that constituted the highest percentage (62\%) of infections in the second wave. Again, our results reflect a change in the risk groups in the second wave where young people including the school going age were infected and probably escalated the spread infections in their communities. Previously in several studies, the virus was more reported in adults aged 40 years and above including disease severity presentation (16). In our current study, we found that the virus was affecting all age groups especially the young ones. We also report mortalities ranging from 1$3.7 \%$ among the infected young ones aged 13 to 39 years which was not the case in the first wave. We strikingly noted high cases of underlying conditions (high blood pressure and diabetes) among the young COVID-19 positive cases aged 20-39 years. This observation is surprising and may explain the increased numbers of severe cases and hospitalizations observed and reported in the second wave. Whereas it has been severally reported that COVID-19 remains limited in young ones in terms of numbers, disease presentation and clinical outcomes, our study suggests otherwise. We think, there has been limited attention and focus to this age group as most cases would probably remain asymptomatic and rarely 
tested. During KIIs, it was reported that the COVID-19 positivity rate was high up to $70 \%$ among students returning from boarding schools upon closure of schools in the second lockdown in June, 2021. Hence, our results call for a shift in outbreak response strategies to address the current disparities and prioritize women and young generations for interventions like vaccinations and specific awareness messages targeting this category to prevent further widespread of infections.

We found that the majority of the cases reported having several and varying symptoms during the course of the disease where most of them reported cough, headache, runny nose, fever, and general body weakness as previously reported $(17,18)$. We further observed poor healthcare seeking behaviours among the COVID-19 cases in our study where $18.3 \%$ of cases never sought care at all and $81.7 \%$ sought for care after experiencing COVID-19 symptoms. Even among those who sought healthcare, went after experiencing advanced stages of the disease with severe symptoms like difficult breathing as verified by the information from in-depth interviews. Whereas the studied COVID-19 cases presented themselves for testing having experienced COVID-19 like symptoms, the biggest proportion (91.3\%) were sent back home for Home Based Care Management (HBCM) as designated COVID-19 treatment units were overwhelmed with severe cases. Ministry of Health had established and approved HBCM guidelines $(19,20)$ and rolled them out to decongest designated COVID-19 treatment units. Unfortunately, the HBC guidelines were rolled out without a proper strategy for implementation and supervision and hence families with COVID19 cases were not sure of what to do, lacked supervisory support and were not able to adhere to SOPs within the guidelines. There is need for massive sensitization of the public about new policies by the relevant authorities to increase compliance.

Our study further noted that a significant number of respondents pointed to health workers as a possible driver of the second wave because they lacked adequate Personal Protective Equipment which compromised their work and exposed them to the risk of being infected. The exposed health workers before testing positive continued to interact with other patients, members of their families and communities, an exposure factor for virus transmission. One more critical area of concern identified during our study, was social gatherings that continued to take place unbated despite of government directives on social gatherings like burials, weddings, churches, bars and restaurants, salons, markets, public transport and schools. SOPS like wearing of facemasks, social distancing of at least 2 meters, minimum numbers recommended of some social functions and hand washing with soap/sanitizers were not being observed, ignored or even completely forgotten. Respondents of KIls and in-depth interviews castigated that the non-adherence to SOPS for social gatherings accelerated the number of cases in most communities observed in the second wave. Even the schools that were opened in the staggered manner with prior preparations and clear instructions to curtail transmissions within the schools, became a seed bed for COVID-19 transmissions. The schools flaunted instructions and some concealed information of COVID-19 cases for fear of being closed. By the time the schools were closed again in June, 2021, the cases both identified and unidentified were very high and further contributed to community transmissions upon returning home. As much as our school situation and operational settings may be different with so many boarding schools compared to other regions of the world, schools (students and teachers) had been reported as one of the super spreaders of SARS-CoV-2 $(21,22)$. The social gatherings were further 
fueled by stigma, social media misinformation and falsifications that circulated widely about COVID-19 that affected many of the instituted prevention measures as also reported elsewhere (23).

At the time of the study and during the study period, COVID-19 vaccine access was extremely very low and only $4 \%$ of the studied COVID-19 cases had received two doses of AstraZeneca vaccine. At national level, only less than $2 \%$ of the targeted population had received 2 doses of the vaccine (24). Hence, the biggest percentage of the population remained naïve and vulnerable to SARS-CoV-2 infections and associated severe disease outcomes especially among the elderly and those with comorbidities. In addition to have a vulnerable population, Uganda also registered and reported existence COVID-19 variants (Delta, Eta, Alpha, Beta and local strain) in June, 2021 (25, 26). Low vaccination coverage together with emergence COVID-19 variants could have attributed to high numbers of COVID-19 cases and associated mortalities registered in June, 2021 alongside others factors already described in this study.

\section{Conclusion}

Our study identified several drivers under the broad categories of demographic, patient, health facilities and services, social and economic factors that attributed to emergence and sustenance of COVID-19 second wave from March to June, 2021. Specifically, being female, young, asymptomatic, under HBCM, social gatherings, school going, not vaccinated were among the major drivers of the second wave. We strongly recommend that the Ministry of Health together with National Taskforce for COVID-19 Response to reconsider some aspects of Home-Based Care Management to only established institutions and organizations with potential and facilities to monitor cases in addition to training and monitoring all those involved in supporting the HBCM. Targeted proactive community (youth, women, traders) engagements to adhere and observe SOPs and other government directives should be prioritized by COVID 19 National Task Force and other stakeholders throughout the country in order to prevent the likelihood of further spread and emergence of the additional waves.

Properly planned and phased easing of the lockdown measures should be guided by the surveillance data followed by proactive enforcement of the established measures and securing the needed vaccines to protect the population. In order to attain the projected scenarios, all stakeholders (Policy makers, health workers, non-government organizations, public and researchers) need to work together to address the health, social and economic impact COVID-19 in formulating policies and designing strategies aimed at curtailing further spread of COVID-19 in our communities.

\section{Methods}

\section{Study Location}

The study was conducted in 10 selected districts in Uganda. Uganda is a land locked country that lies between $1^{0} 29^{\prime}$ South and $4^{0} 12^{\prime}$ North latitude, $29^{0} 34^{\prime}$ East and $35^{\circ} 0^{\prime}$ East longitude (27). 
Uganda has a population of 41.6 million people based on the Uganda National Household Survey (UNHS) conducted in 2019/20 by the Uganda Bureau of Statistics (UBOS). More than half (54\%) of the population is below 18 years of age. Uganda, just like other Sub-Saharan African countries, has a weak health care system characterized by low clinician to patient ratio, limited laboratory capacity, poor administration, and limited resources $(28,29)$.

\section{Study Setting}

In this study, we selected 10 districts (figure 1) representing the main geographic regions that had the highest number of COVID-19 cases as reported by the $\mathrm{MOH}$ (5). The selected districts were the border districts (Busia and Tororo) with Points of Entry (PoE); major road highways for transit of cargo across districts (Mbale, Gulu, Luwero, Soroti, and Moroto districts); and highly populated regional city districts (Wakiso, Gulu, Mbarara and Kampala) $(30,31)$.

\section{Study population}

The study population included patients or care givers (especially for children below 18 years) of people who had suffered and recovered from COVID-19, either after HBC or discharge from health facilities. The retrospective cross-sectional study was done as part of the outbreak investigation from March to June 2021 for PCR/RDT confirmed cases.

\section{Sample size and sampling procedure}

Sampling: We selected 10 districts based on their high population densities, high incidences of COVID-19 cases from March 2021 to June 2021 exceeding 300 cumulative cases in the study period, and having PoEs within the districts. We obtained data on COVID- 19 positive RDT/PCR results from the MOH COVID19 lab investigation forms available at respective health facilities in the study districts (sample form appendix 1). The information extracted was then used to systematically sample (Table 7) and locate the recovered COVID-19 cases who were interviewed in the community.

We further conducted 38 Key Informants Interviews (KIIs) and 19 In-depth Interviews of purposefully selected respondents in all districts under study using guide (Appendix 3 ). The Key Informants comprised COVID-19 District Task Force (DTF) members based on their knowledge and active participation in the COVID-19 outbreak response interventions (appendix 2).

\section{Table 7: Recruitment protocol}




\begin{tabular}{|l|l|}
\hline $\begin{array}{l}\text { Confirmed COVID-19 cases (RDT/PCR) in the MOH dashboard on 15 th } \\
\text { June } 2021\end{array}$ & 67,215 \\
\hline Sample size estimated at national level from 10 high transmission districts & 1,200 \\
\hline Eligible populations in high transmission districts & 1,200 \\
\hline Accessed population and those who consented to the study & $\begin{array}{l}1,120 \\
(93.3 \%)\end{array}$ \\
\hline
\end{tabular}

\section{Data collection, Management and Analysis}

\section{h. Quantitative data}

Quantitative data was collected by trained and experienced epidemiologists using of open-ended semistructured questionnaires (appendix 3) uploaded on the mWater portal (@mWater,2021), an open-source cloud-based web application deployed on the Android tablets. First, we obtained the details of the case listings in a Microsoft excel from the national database of COVID-19 cases at $\mathrm{MOH}$ that guided the selection of target districts with cases ranging from 100-150 cases per district. We then proceeded to the targeted districts to further access records for COVID-19 cases for verification and selection of participants.

The field team further accessed laboratory investigation forms of the COVID-19 PCR and RDT positive cases from the laboratories of the selected health facilities in each of the selected districts to extract data on variables such as; social demographics and clinical symptoms. The collected information was then used to locate the recovered COVID-19 cases in respective communities guided by the Community health workers. The selected cases were called via telephone to arrange appointments before the visits. On the day of the visit, the field team consented the participant and then collected data from each participant using a community COVID-19 case questionnaire that was adopted from the $\mathrm{MOH}$ standard tool which assessed the social demographics and clinical characteristics of the COVID-19 positive cases. All the data collected on tablets was uploaded daily onto a mWater portal server secured with passcodes that was only accessed by the principal investigators.

\section{Analysis}

The collected data was exported and cleaned using MS Excel 2016 (Microsoft Corporation, Redmond, WA) and analyzed using STATA 15.0 statistical software (StataCorp, Texas USA). Descriptive analyses were performed for demographic characteristics, and clinical characteristics of the COVID-19 cases were presented as frequencies, proportions and means where appropriate. Being either symptomatic (coded 0 ) or asymptomatic/not symptomatic (coded 1) was considered as the outcome variable. To assess the association between the outcome variable and the explanatory variables, we considered a generalized linear model of the Poisson family with a logarithm as the conical link function with a robust error 
variance. This resulted into Crude Prevalence Ratios (CPR) at 95\% confidence intervals. Furthermore, variables with a threshold P-value less than 0.05 (P-value $<0.05)$ at bivariate analyses were subjected to the multivariable regression analyses to adjust for confounding, thus establishing Adjusted Prevalence Ratios (APR). At multivariable analysis, only variables with a P-value less than 0.05 were considered significant. Both the CPR and APR have been reported.

\section{i. Qualitative data}

Data collection: An in-depth and key informant guide (appendix 3) was used to conduct interviews with members of the communities in the selected districts who had contracted COVID-19 and the DTF members respectively. The main theme explored was drivers of the COVID-19 transmissions and spread during the second wave. Consent was obtained verbally before the interview of the respondents who were purposively selected for KIIs and in-depth interviews. From each district, 4 respondents ( 2 male and 2 female) who had contracted COVID-19 were interviewed during in-depth interviews. Both the KIIs and Indepth interviews were recorded using smartphones and tablets and the audios transcribed verbatim into Microsoft Word that were only accessed by the study team. The transcripts were proofread while listening to the original audios by the two-independent researchers for accuracy and consistence.

Analysis: Qualitative data was analyzed using manual thematic analysis, diverging, converging and emerging themes with representative quotes that were obtained during the analysis. The outputs of these findings are presented in table 8 in the appendices.

\section{Abbreviations}

COVID-19

Corona Virus Disease 2019

HBCM

Home Based Care Management

SARS CoV2

Severe acute respiratory syndrome coronavirus 2

SOPs

Standard Operating Procedures

PCR

Polymerized Chain Reaction

RDC

Resident District Commissioner

DHO

District Health Officer

\section{Declarations}




\section{Ethical approval and consent to participate}

The study was undertaken as part of COVID-19 rapid response surveillance under the Presidential Scientific Initiative on Epidemics (PRESIDE), statehouse, Uganda. This study was submitted to Makerere University School of Biomedical Sciences Research Ethics Committee (SBS REC) and the need for approval was waived following guidance by Technical Inter-sectoral Committee and Enforcement on COVID-19 Response as it was considered an outbreak investigation to explain why COVID-19 cases were increasing steadily. Permission was also obtained from districts' leadership at sub national level who provided letters of administrative clearances. All study participants consented to participate in the study and the data obtained was secured and kept under lock and key. The field team individually signed the confidentiality agreement before commencement of the study.

\section{Consent for publication}

Not applicable

\section{Availability of data and materials}

All the project materials and data about this project are available. These can be accessed by contacting the first author (Abel Wilson Walekhwa) on wabelwilson@gmail.com.

\section{Competing Interests}

All authors declare no financial and non-financial competing. All authors confirm that we have had full access to all the data in the study and accept responsibility to submit for publication.

\section{Funding}

The funding for this outbreak Investigation was obtained from statehouse, Uganda under the Presidential Scientific Initiative on Epidemics (Epidemics Unit). The Epidemics Unit is mandated to collect, analyze all epidemiological data to inform national policies in the control and management.

\section{Authors' Contributions}

AWW, MM, LM, ABE, BN, MN, TT, GN; Conceptualized the study, designed study protocol, processed ethical approvals, conducted data collection, developed the first draft of the manuscript. BA, RWM, DB ${ }^{2}, C N$, MDN; Participated in data collection, data analysis, reviewed the first manuscript draft. DB ${ }^{6}, \mathrm{STW}, \mathrm{RWM}$, $\mathrm{DB}^{2}, \mathrm{CN}$; Technically guided in data analysis, reviewed the manuscript revisions. $\mathrm{DB}^{6}$ and $\mathrm{LM}$ verified all underlying data. MM mobilized resources for study and gave technical supervision for the field teams. All authors reviewed and approved the final version of the manuscript.

\section{Acknowledgement}


We would like to thank all the Respondents for providing the necessary information that made this study a success. Further appreciation goes to the district leadership who actively participated in this study. We want to thank the President of republic of Uganda for entrusting us with the mandate of Epidemic preparedness at Presidential Scientific Initiative on Epidemics (PRESIDE) and allocating us funds in the Financial year 2020/21 that enabled us conduct this study. We also appreciate a team of field epidemiologists who supported us in data collection. Our sincere appreciation goes to the districts' leadership who accorded us audience and permitted us to visit the cases.

\section{References}

1. WHO. COVID-19 Public Health Emergency of International Concern (PHEIC) Global research and innovation forum 2020 [cited 2021 9th October 2021]. Available from: https://www.who.int/publications/m/item/covid-19-public-health-emergency-of-international-concern(pheic)-global-research-and-innovation-forum.

2. Parker RWJALR. Why America's Response to the COVID-19 Pandemic Failed: Lessons from New Zealand's Success. 2021;73:77, -9.

3. JHU. Statistics COVID-19 New cases and deaths 2021. Available from:

https://github.com/CSSEGISandData/COVID-19.

4. Cucinotta D, Vanelli M. WHO declares COVID-19 a pandemic. Acta Bio Medica: Atenei Parmensis. 2020;91(1):157.

5. Ministry of Health M. Ministry of Health website2020 [updated April 03, 2020; cited 2021

7/17/2021]. Available from: https://www.health.go.ug/covid/2020/04/02/update-on-the-covid-19response-in-uganda/.

6. Kitara DL, Ikoona ENJTPAMJ. COVID-19 pandemic, Uganda's story. 2020;35(Suppl 2).

7. Keni R, Alexander A, Nayak PG, Mudgal J, Nandakumar K. COVID-19: Emergence, Spread, Possible Treatments, and Global Burden. Frontiers in public health. 2020;8:216.

8. Ferguson N, Laydon D, Nedjati Gilani G, Imai N, Ainslie K, Baguelin M, et al. Report 9: Impact of non-pharmaceutical interventions (NPIs) to reduce COVID19 mortality and healthcare demand. 2020.

9. Mahmud M, Riley E. Household response to an extreme shock: Evidence on the immediate impact of the Covid-19 lockdown on economic outcomes and well-being in rural Uganda. World Development. 2021;140:105318.

10. Ssali SN. Gender, Economic Precarity and Uganda Government's COVID-19 Response. African Journal of Governance \& Development. 2020;9(1.1):287-308. 
11. Uganda records surge in Covid-19 cases amid alarming death rates [press release]. African News: African News, 11/June/2021 2021.

12. Kirenga B, Muttamba W, Kayongo A, Nsereko C, Siddharthan T, Lusiba J, et al. Characteristics and outcomes of admitted patients infected with SARS-CoV-2 in Uganda. 2020;7(1):e000646.

13. Holler JG, Eriksson R, Jensen Tø, Van Wijhe M, Fischer TK, Søgaard OS, et al. First wave of COVID19 hospital admissions in Denmark: a Nationwide population-based cohort study. 2021;21(1):1-16.

14. Isralowitz R, Konstantinov V, Gritsenko V, Vorobeva E, Reznik AJJoL, Trauma. First and second wave COVID-19 impact on Russian medical student fear, mental health and substance use. 2021;26(1):94-6.

15. Avadhanula V, Nicholson EG, Ferlic-Stark L, Piedra F-A, Blunck BN, Fragoso S, et al. Viral load of SARS-CoV-2 in adults during the first and second wave of COVID-19 pandemic in Houston, TX: the potential of the super-spreader. 2021.

16. Kirenga B, Muttamba W, Kayongo A, Nsereko C, Siddharthan T, Lusiba J, et al. Characteristics and outcomes of admitted patients infected with SARS-CoV-2 in Uganda. BMJ Open Respiratory Research. 2020;7(1):e000646.

17. Guan W-j, Ni Z-y, Hu Y, Liang W-h, Ou C-q, He J-x, et al. Clinical Characteristics of Coronavirus Disease 2019 in China. New England Journal of Medicine. 2020;382(18):1708-20.

18. Huang C, Wang Y, Li X, Ren L, Zhao J, Hu Y, et al. Clinical features of patients infected with 2019 novel coronavirus in Wuhan, China. The Lancet. 2020;395(10223):497-506.

19. Organization WH. Home care for patients with COVID-19 presenting with mild symptoms and management of their contacts: interim guidance, 17 March 2020. World Health Organization, 2020.

20. Operational guidelines on COVID 19 for COVID 19 for VHTs [press release]. 2021.

21. Wada K, Okabe N, Shobugawa YJBPO. Infection and transmission of COVID-19 among students and teachers in schools in Japan after the reopening in June 2020. 2020;4(1).

22. Varma JK, Thamkittikasem J, Whittemore K, Alexander M, Stephens DH, Arslanian K, et al. COVID19 infections among students and staff in New York City public schools. 2021;147(5).

23. Schmidt T, Cloete A, Davids A, Makola L, Zondi N, Jantjies MJPo. Myths, misconceptions, othering and stigmatizing responses to Covid-19 in South Africa: A rapid qualitative assessment. 2020;15(12):e0244420.

24. MOH. MINISTRY OF HEALTH - UGANDA NATIONAL EXPANDED PROGRAM ON IMMUNISATION UPDATES ON COVID-19 VACCINATION CAMPAIGN. 2021 15th May 2021. Report No. 
25. Nakkazi E. Five Virus Variants Fuel Second Wave of COVID-19 in Uganda. Health Policy Watch: 2021.

26. UPDATE ON COVID-19 RESPONSE 2RD JULY 2021 [press release]. 2nd JULY 20212021.

27. UBoS U. The national population and housing census 2014-national analytical report. Kampala, Uganda. 2017.

28. El-Sadr WM, Justman J. Africa in the Path of Covid-19. The New England journal of medicine. 2020;383(3):e11.

29. Peter T, Keita MS, Nkengasong J. Building laboratory capacity to combat disease outbreaks in Africa. African journal of laboratory medicine. 2016;5(3):579.

30. AfricanNews. Coronavirus - Uganda: COVID-19 update (16 April 2021). 2021.

31. Olukya G. Uganda hospitals run short of oxygen amid spike in COVID-19 cases 2021 [cited 2021 7/16/2021]. Available from: https://www.aa.com.tr/en/africa/uganda-hospitals-run-short-of-oxygenamid-spike-in-covid-19-cases/2275032.

\section{Tables}

Table 1 is in the supplementary files section.

Table 5: Showing characteristics of asymptomatic patients 


\begin{tabular}{|c|c|c|c|c|c|c|}
\hline \multirow[t]{2}{*}{ Variable } & \multicolumn{2}{|c|}{ Outcome } & \multirow{2}{*}{$\begin{array}{l}\text { CPR at } 95 \% \\
\text { CI }\end{array}$} & \multirow{2}{*}{$\begin{array}{l}\mathrm{P} \text { - } \\
\text { value }\end{array}$} & \multirow{2}{*}{$\begin{array}{l}\text { APR at } \\
95 \% \text { CI }\end{array}$} & \multirow{2}{*}{$\begin{array}{l}\text { P- } \\
\text { value }\end{array}$} \\
\hline & $\begin{array}{l}\text { Asymptomatic } \\
(\mathrm{n}=225)\end{array}$ & $\begin{array}{l}\text { Symptomatic } \\
(\mathrm{n}=895)\end{array}$ & & & & \\
\hline \multicolumn{7}{|l|}{ Sex } \\
\hline Male & $114(21)$ & 429 (79) & - & & & \\
\hline Female & $111(19.2)$ & $466(80.8)$ & $\begin{array}{l}0.92(0.725- \\
1.158)\end{array}$ & 0.464 & & \\
\hline \multicolumn{7}{|l|}{ Age } \\
\hline$\leq 40$ & $160(21.7)$ & $578(78.3)$ & - & & & \\
\hline $41 \geq$ & 65 (17) & 317 (83) & $\begin{array}{l}0.78(0.605- \\
1.018)\end{array}$ & 0.068 & & \\
\hline \multicolumn{7}{|l|}{ Age } \\
\hline$\leq 10$ & $6(15.4)$ & $33(84.6)$ & - & & & \\
\hline $11-20$ & 38 (26.2) & $107(73.8)$ & $\begin{array}{l}1.70(0.777- \\
3.736)\end{array}$ & 0.184 & & \\
\hline $21-30$ & $52(20.5)$ & $202(79.5)$ & $\begin{array}{l}1.33(0.613- \\
2.889)\end{array}$ & 0.470 & & \\
\hline $31-40$ & $64(21.3)$ & 236 (78.7) & $\begin{array}{l}1.39(0.643- \\
2.988)\end{array}$ & 0.404 & & \\
\hline $41 \geq$ & 65 (17) & 317 (83) & $\begin{array}{l}1.11(0.513- \\
2.386)\end{array}$ & 0.797 & & - \\
\hline
\end{tabular}

\section{Household size}

\begin{tabular}{|c|c|c|c|c|c|c|}
\hline$\leq 5$ members & $140(23)$ & 470 (77) & - & & - & \\
\hline \multirow[t]{3}{*}{$6-8$} & 61 (17.7) & $284(82.3)$ & $0.77(0.588-$ & 0.059 & 0.79 & 0.227 \\
\hline & & & 1.01) & & (0.536- & \\
\hline & & & & & 1.160) & \\
\hline \multirow[t]{3}{*}{$9 \geq$} & $24(14.6)$ & $141(85.4)$ & $0.63(0.426-$ & 0.025 & 0.69 & 0.241 \\
\hline & & & $0.943)$ & & (0.379- & \\
\hline & & & & & 1.276) & \\
\hline
\end{tabular}

\section{Vaccination status}

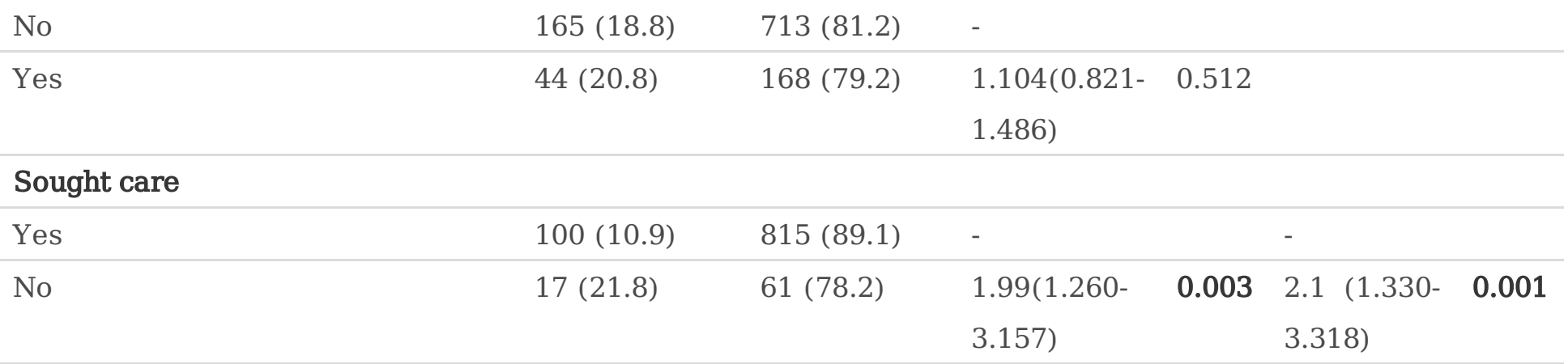




$\begin{array}{lllllll}\text { Yes } & 10(9.8) & 92(90.2) & - & - & \\ \text { No } & 214(21) & 803(79) & 2.15(1.177- & \mathbf{0 . 0 1 3} & 3.54 & 0.027 \\ & & & 3.914) & & (1.151- & 10.9)\end{array}$

\section{Other Household members got} symptoms

$\begin{array}{lllllll}\text { Yes } & 78(14.9) & 447(85.1) & - & - & \\ \text { No } & 128(22.6) & 438(77.4) & 1.52(1.179- & \mathbf{0 . 0 0 1} & 0.72(0.502- & 0.068 \\ & & & 1.965) & 1.024) & \end{array}$

Had contact with someone with COVID-19 like symptoms 2 weeks before

\begin{tabular}{|c|c|c|c|c|c|c|}
\hline No & $64(31.4)$ & 140 (68.6) & - & & - & \\
\hline \multirow[t]{2}{*}{ Yes } & $29(12)$ & $212(88)$ & $0.38(0.258-$ & 0.000 & $0.16(0.083-$ & 0.000 \\
\hline & & & $0.571)$ & & 0.309) & \\
\hline \multirow[t]{2}{*}{ Don't remember } & 131 (19.5) & $540(80.5)$ & $0.62(0.482-$ & 0.000 & $0.35(0.244-$ & 0.000 \\
\hline & & & $0.803)$ & & $0.492)$ & \\
\hline
\end{tabular}

Table 8: Respondents quotes from KII and In-depth COVID-19 interviews 


\begin{tabular}{|c|c|}
\hline $\begin{array}{l}\text { Categories of } \\
\text { KII and In- } \\
\text { depth interview } \\
\text { responses }\end{array}$ & Summary quotes from respondents \\
\hline $\begin{array}{l}\text { Home Based } \\
\text { Care (HBC) }\end{array}$ & $\begin{array}{l}\text { "...you see when home-based care was introduced, the situation got out } \\
\text { of hand because after testing positive for COVID-19, people went back } \\
\text { to their workplaces such as the salon or shop even though they had } \\
\text { mild symptoms like; flu, fever or cough. So, I think that is the biggest } \\
\text { driver..." Assistant District Health Officer, District A. } \\
\text { "I was going to be put on oxygen but it was a lot of money, they were } \\
\text { asking me } 1.5 \text { million per day yet we didn't know how long I was going } \\
\text { to be there, whether a week. And so, the health worker said that, "my } \\
\text { advice to you is if you can get some money to buy this medicine, you } \\
\text { treat yourself from home." So, I went back home. I am here with my } \\
\text { wife who also contracted COVID-19 and she got treatment and } \\
\text { recovered." IDI Male, District W. } \\
\text { "Since I wasn't that severely sick, I decided to stay home under home } \\
\text { based care."IDI } 1 \text {, District A. } \\
\text { "...the good thing I was asymptomatic so I isolated from home." IDI 2, } \\
\text { District A. }\end{array}$ \\
\hline $\begin{array}{l}\text { Social } \\
\text { Gatherings }\end{array}$ & $\begin{array}{l}\text { "...We have recorded quite a number of COVID-19 cases from our } \\
\text { markets ...I'm talking about vendors, not even the customers but the } \\
\text { vendors..." DHO, District W. } \\
\text { "You know when the president allowed food markets to operate but } \\
\text { was not strict on this issue of attendance in the market. The vendors } \\
\text { still moved to their homes and interacted with people in the market } \\
\text { then they go and stay with their families...." LC5, District S. } \\
\text { "...And then also bars, you find that most of them are still stealthily } \\
\text { operational and those are areas that increase spread faster." LC5, } \\
\text { District S. } \\
\text { "...Last time they said that bars are closed but they are very open, a } \\
\text { drunkard can't put on a mask. So, all these things lead to an increase in }\end{array}$ \\
\hline
\end{tabular}




\begin{tabular}{|c|c|}
\hline & $\begin{array}{l}\text { cases. One person can infect } 100 \text { people when they are together...." IDI } \\
\text { Female, District M. } \\
\text { "...They tell them ...not to go for burials, and they don't listen because } \\
\text { they want to go and bid farewell to their community member and you } \\
\text { just wonder because the person has died of COVID-19. And we know } \\
\text { that at the burial of a COVID victim, the chances of having other } \\
\text { infected persons are high hence spreading infection in the whole } \\
\text { community. There was a burial around here and people slept over } \\
\text { saying that it's impossible not to do it. Even if you advise them to let a } \\
\text { few stay, they don't listen and you wonder if they are all going to be } \\
\text { tested or not and you know at least } 10 \text { are infected. Because they } \\
\text { cuddled the widow, welcomed her with hugs, and they sat in } \\
\text { house...."VHT, District A. }\end{array}$ \\
\hline $\begin{array}{l}\text { Myths, } \\
\text { Misconceptions } \\
\text { and } \\
\text { Misinformation }\end{array}$ & $\begin{array}{l}\text { "...the community in the district still say there is no COVID... and they do } \\
\text { not put on masks...." IDI Male, District B. } \\
\text { "...Another driver is that information and technology that has given } \\
\text { freedom to people to publish anything on COVID-19 yet social media } \\
\text { tends to be highly consumed by the community...." District Surveillance } \\
\text { Focal Person, District T. }\end{array}$ \\
\hline Politics & $\begin{array}{l}\text { "...you see, the campaigns were the key drivers of the second } \\
\text { wave...." District Medical Officer, District } \mathrm{P} .\end{array}$ \\
\hline Schools & $\begin{array}{l}\text { "... The number of cases that came from school are increasing because } \\
\text { in terms of positivity the rate was at around } 70 \% \text { in that out of every } \\
\text { ten individuals we were testing from the schools, seven were } \\
\text { positive." DHO, District W. }\end{array}$ \\
\hline $\begin{array}{l}\text { Weak Health } \\
\text { Systems }\end{array}$ & $\begin{array}{l}\text { "...the factor of inadequate resources to confine positive cases became } \\
\text { key in spreading the infection...." Resident District Commissioner, } \\
\text { District H. } \\
\text { "...inadequate resources for sensitization because the rural populace } \\
\text { took it as a disease for the urban. "That's your disease." And indeed, if } \\
\text { you go to the rural areas, there's totally no SOPs observed. So } \\
\text { inadequate sensitization in that regard." District Health Officer, District } \\
\text { S. } \\
\text { "...we have seen health workers themselves getting infected. Aaaah. } \\
\text { maybe they are not protected, health workers some of them don't have } \\
\text { PPEs, they don't have what to use, they don't have gloves, uhmm, and } \\
\text { yet they really see patients. For that reason, we have seen health }\end{array}$ \\
\hline
\end{tabular}




\begin{tabular}{|c|c|}
\hline & $\begin{array}{l}\text { workers who have tested positive. Probably they are also the agents of } \\
\text { spreading the disease." District Laboratory Focal Person, District A. } \\
\text { "... On the medical perspective, it is lack of machines to use, the PPEs } \\
\text { and the rest. That has been one of the factors. You find us working } 3 \text { to } \\
4 \text { days but without a mask...." Laboratory Focal Person, District M. } \\
\text { "......just before we got the kits yesterday, people we saw had all the } \\
\text { signs of COVID, they wanted to test but they could not test, so aanha } \\
\text { limited availability of testing points could also have been a driver } \\
\text { because some people have signs but for as long as they have not tested } \\
\text { positive they will not isolate. They put others at risk and yet they know } \\
\text { their status...." Assistant District Health Officer, District A. } \\
\text { "...Then also in our health centers there is a lot of congestion. These } \\
\text { are areas that increase spread faster. Most health centers IIs and IIIs } \\
\text { offer free health services so whoever believes has a challenge goes } \\
\text { there...they tend to handle other cases such as malaria, they don't } \\
\text { handle COVID. Regardless a patient can spend the whole day with } \\
\text { people at the facility hence spreading the disease...." LC5, District S. }\end{array}$ \\
\hline $\begin{array}{l}\text { Money } \\
\text { (Exchange of } \\
\text { goods) }\end{array}$ & $\begin{array}{l}\text { "...the main cause might be money since exchange of money from one } \\
\text { person's hand to another happens when we are buying and/or selling } \\
\text { stuff leading to infection. Also, there are some people, including us who } \\
\text { keep their masks in the same bag where money is kept, money one has } \\
\text { just received from somebody they do not know...." IDI Male, District W. }\end{array}$ \\
\hline Stigma & $\begin{array}{l}\text { "...the stigma is a big driver among those who know their status and } \\
\text { they don't want others to know. So, in that state of hiding, they infect } \\
\text { many...." Assistant District Health Officer, District A. } \\
\text { "... when one gets it, he just hides off, so you will find that the whole } \\
\text { family is being... infected, that is what is causing the problem in the } \\
\text { community...." IDI Male, District B. }\end{array}$ \\
\hline
\end{tabular}

\section{Figures}

\section{Figure 1}

Location of study districts in Uganda. 


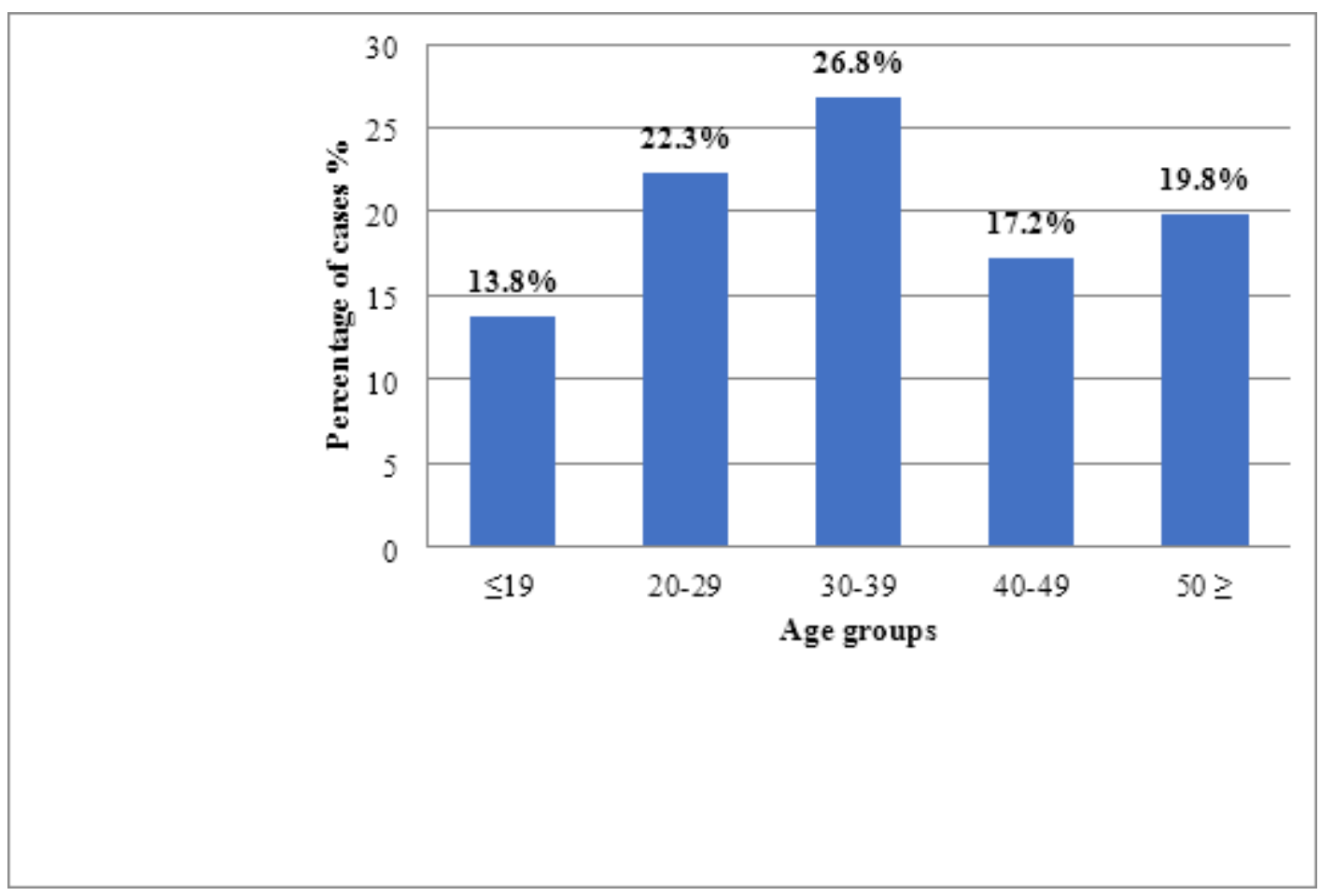

Figure 2

Adjusted age distribution of study participants

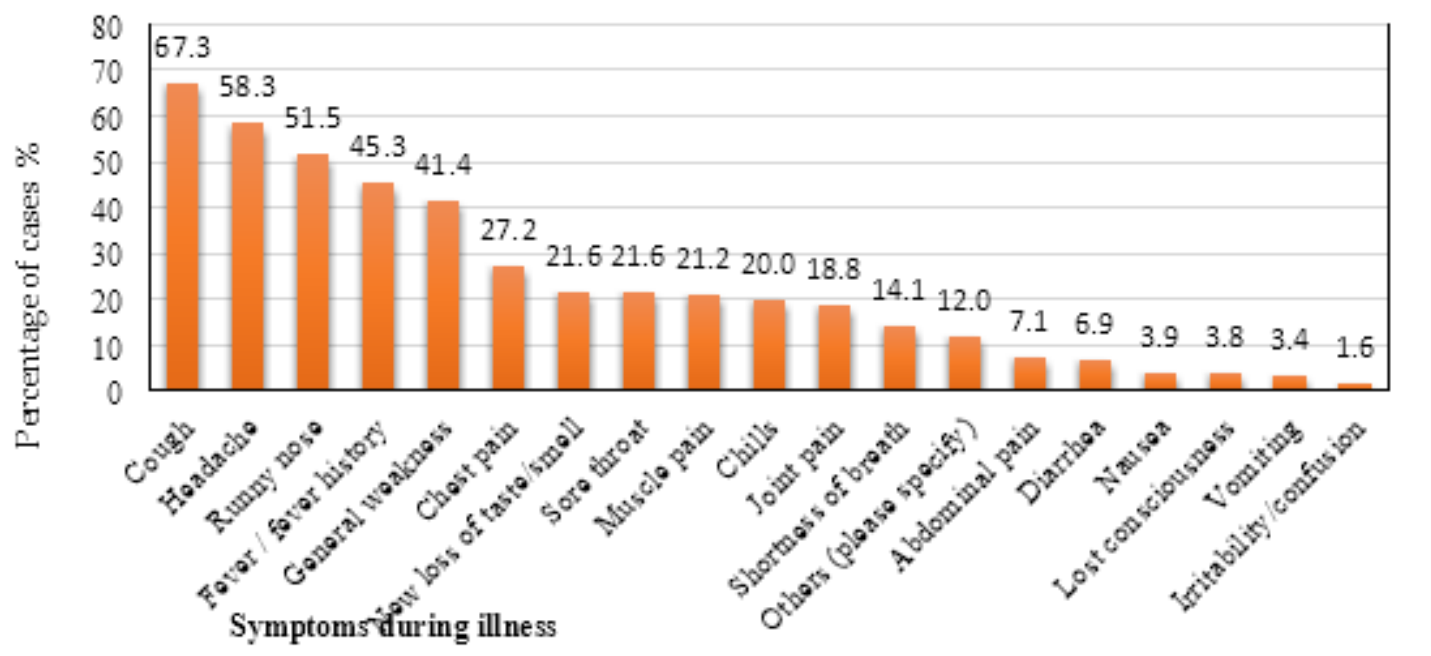

Figure 3

Symptoms experienced during illness

\section{Supplementary Files}

This is a list of supplementary files associated with this preprint. Click to download. 
- Table1.docx

- Appendix.docx 